\title{
Review \\ Mesenchymal Stromal/Stem Cells and Their Products as a Therapeutic Tool to Advance Lung Transplantation
}

\author{
Vitale Miceli ${ }^{1, *(1)}$ and Alessandro Bertani ${ }^{2, *}$ (D) \\ 1 Research Department, IRCCS ISMETT (Istituto Mediterraneo per i Trapianti e Terapie ad alta \\ specializzazione), 90127 Palermo, Italy \\ 2 Thoracic Surgery and Lung Transplantation Unit, IRCCS ISMETT (Istituto Mediterraneo per i Trapianti e \\ Terapie ad Alta Specializzazione), 90127 Palermo, Italy \\ * Correspondence: vmiceli@ismett.edu (V.M.); abertani@ismett.edu (A.B.); Tel.: +39-091-21-92-430 (V.M.); \\ +39-091-21-92-111 (A.B.)
}

check for updates

Citation: Miceli, V.; Bertani, A. Mesenchymal Stromal/Stem Cells and Their Products as a Therapeutic Tool to Advance Lung

Transplantation. Cells 2022, 11, 826 . https://doi.org/10.3390/cells11050826

Academic Editors: Alessandro

Palleschi and Davide Tosi

Received: 1 February 2022

Accepted: 25 February 2022

Published: 27 February 2022

Publisher's Note: MDPI stays neutral with regard to jurisdictional claims in published maps and institutional affiliations.

Copyright: (C) 2022 by the authors. Licensee MDPI, Basel, Switzerland. This article is an open access article distributed under the terms and conditions of the Creative Commons Attribution (CC BY) license (https:// creativecommons.org/licenses/by/ $4.0 /)$.

\begin{abstract}
Lung transplantation (LTx) has become the gold standard treatment for end-stage respiratory failure. Recently, extended lung donor criteria have been applied to decrease the mortality rate of patients on the waiting list. Moreover, ex vivo lung perfusion (EVLP) has been used to improve the number/quality of previously unacceptable lungs. Despite the above-mentioned progress, the morbidity/mortality of LTx remains high compared to other solid organ transplants. Lungs are particularly susceptible to ischemia-reperfusion injury, which can lead to graft dysfunction. Therefore, the success of LTx is related to the quality/function of the graft, and EVLP represents an opportunity to protect/regenerate the lungs before transplantation. Increasing evidence supports the use of mesenchymal stromal/stem cells (MSCs) as a therapeutic strategy to improve EVLP. The therapeutic properties of MSC are partially mediated by secreted factors. Hence, the strategy of lung perfusion with MSCs and/or their products pave the way for a new innovative approach that further increases the potential for the use of EVLP. This article provides an overview of experimental, preclinical and clinical studies supporting the application of MSCs to improve EVLP, the ultimate goal being efficient organ reconditioning in order to expand the donor lung pool and to improve transplant outcomes.
\end{abstract}

Keywords: lung transplantation; ex vivo lung perfusion; mesenchymal stromal/stem cells; cell therapy; lung preservation; lung reconditioning

\section{Introduction}

Lung transplantation (LTx) has become the treatment of choice for patients with end-stage respiratory failure and, over the past decades, the worldwide survival of lung transplant patients has increased significantly [1]. Unfortunately, the short- and long-term outcomes of LTxs are still less favorable than other solid organ transplants, the main faults being organ shortage and the fact that more than $80 \%$ of potential organ donors are not suitable or used for transplantation [2-6]. Moreover, other factors, such as postoperative graft dysfunction (PGD), infections, and rejection may also contribute to post-transplant mortality $[7,8]$.

Although the use of extended-criteria lung donors and donors after cardio-circulatory death is increasing, there is still wide consensus in the transplant community that a large proportion of potentially viable grafts is discarded due to fear of early graft dysfunction and the increased postoperative morbidity and mortality of the recipient $[1,3,9,10]$. Ischemiareperfusion injury (IRI) is the leading cause of early postoperative lung dysfunction, and is characterized by alveolar damage and lung edema usually occurring within 72 hours after LTx [11]. These pathological processes are driven by both oxidative stress and inflammatory pathways, which cause significant damage to the lung parenchyma, leading to the development of early PGD and consequent chronic lung allograft dysfunction [1,10-12]. 
Therefore, a reduction in these adverse effects could significantly improve the success of LTx.

Recently, it has been shown that the use of normothermic ex vivo lung perfusion (EVLP) may be helpful in increasing the number and improving the results of lung transplantation $[13,14]$. This procedure provides the opportunity to evaluate donor lung function, and different treatments can also be used to further reduce IRI [15-17]. Therefore, the improvement of this technique represents a promising strategy to increase the number of suitable organs and to advance LTx.

A suitable approach to improving EVLP technique consists of using mesenchymal stromal/stem cells (MSCs) and/or their secretome, which contains extracellular vesicles (EVs, such as exosomes and EXOs) and other bioactive molecules, including cytokines, chemokines, growth factors, angiogenic and immunomodulatory factors [18-21]. Although the mechanisms are not fully defined yet, it has been widely demonstrated in both preclinical and clinical studies that therapeutic effects of MSCs are mediated, at least in part, by paracrine factors [21-24]. MSCs' therapeutic properties have been also evaluated in a phase II clinical trial to treat acute respiratory distress syndrome (ARDS) [25]. MSCs and/or their products are able to mitigate both lung injury and inflammation in different experimental models, and the infusion of MSCs protects transplanted lungs from IRI [26-29]. Moreover, it has been found that MSC-based treatment during EVLP is associated with a decrease in ischemic injury of human donor lungs [30-32]. In this case, to avoid the founding of infused MSCs in the lung parenchyma, cell-free therapies, including the use of MSC-derived EXOs and MSC-derived conditioned medium (CM), could be considered new approaches to obtaining MSCs' beneficial effects. EXOs are nanosized structures carrying functional molecules [33], and can be considered a promising therapeutic tool for acute lung injury because they reduce inflammation and enhance tissue regeneration [34-36]. Similarly, MSC-derived CM has demonstrated beneficial effects on lung diseases [37-43]. The use of MSC-derived products rather than direct use of MSCs can prevent all the risks associated with live-cell transplants. Therefore, the use of these products is emerging as a promising approach in the field of LTx. In this review, we describe the therapeutic properties of MSCs and their products as promising tools to improve EVLP techniques, with the ultimate goal of advancing LTx outcomes.

\section{Current Challenges in Lung Transplantation}

Lung transplantation has become the gold standard treatment for patients with endstage lung disease. According to recent data, approximately 4,600 transplants are performed every year worldwide, and $80 \%$ are bilateral [44]. Although the results of LTx have significantly improved during the past twenty years, morbidity and mortality remain high when compared with other solid organ transplants $[6,44]$. One central issue in lung transplantation is the chronic shortage of donors. This is related to both the donor pool (which should be expanded) and the need for better lung preservation techniques to convert a usually unsuitable organ into an organ exploitable for transplantation. Therefore, our understanding of lung biopathology and the implementation of new techniques/treatments capable of expanding the lung donor pool will have a significant impact in the field.

\subsection{Donor Shortage and Expansion of Donor Pool}

Although the number of LTxs worldwide has been steadily increasing over the past decade, there is still a significant imbalance between the number of available donors and patients' needs, and mortality on the waiting list is still high. An improvement was achieved thanks to the introduction of the lung allocation score (LAS), which was implemented in the United States in 2005 and is still under refinement [45]. The LAS significantly decreased deaths on the waiting list without affecting overall post-transplant outcomes [46]. However, the number of patients dying on the waiting list is still high, and the shortage of grafts persists [47]. This scenario is not only due to the shortage of available donors, but also to the low utilization rate of donor lungs. Indeed, it has been evaluated that a 
large number of multiorgan donors are not suitable for LTx $[3,13]$ and, in particular for donation after circulatory death (DCD), lungs are considered eligible for transplantation in only $2 \%$ of cases [13]. Potentially suitable lungs are deemed ineligible for transplant due to various criteria, including the donor history, pneumonia, chest trauma, aspiration, purulent secretions, positive sputum gram stain, or inadequate gas exchanges $[1,48,49]$. This long list makes it clear why only $15-20 \%$ of donated lungs are allocated. During the last decade, the use of extended donor criteria, including DCD donor-derived lungs, has emerged as a promising approach for increasing the donor pool. Controlled and uncontrolled DCD lung donation has emerged as a promising strategy to retrieve viable lungs for transplantation, although the legislation on declaration of death can vary in different countries and can pose a significant limitation to this process [48]. The use of DCD in LTx has been met with growing interest following the suggestion in different reports that up to $30 \%$ more donors could be recruited by this approach [50-52]. Indeed, although there is no general consensus on the use of DCD lungs (because of the potential for lung damage resulting from this strategy), the growing scientific evidence has demonstrated similar or superior outcomes with DCD donor lungs compared to lungs derived from brain dead patients $[48,53]$. Interestingly, in the case of uncontrolled DCD (where the donation is made after unexpected out-of-hospital cardiac arrest), due to both the prolonged warm ischemia time post-mortem and the inability for pre-procurement assessment of the lungs, the use of EVLP is strongly recommended before LTx [54]. In this case, EVLP becomes crucial, because it allows the assessment of the lungs and facilitates timing and logistics for LTx management [55]. The combined use of uncontrolled DCD with EVLP in LTx may represent a useful strategy to successfully expand the donor pool.

\subsection{Lung Preservation by Ex Vivo Lung Perfusion (EVLP)}

Ex vivo lung perfusion (EVLP) is a promising technique for the evaluation and recovery of compromised donor lungs. Following preliminary results produced since 1990 by Steen and collaborators [56,57], the Toronto lung transplant group, in 2011, demonstrated that EVLP is feasible in clinical practice [58]. During EVLP, the lungs are placed into a device providing ventilation and perfusion for 4-6 h [58-60]. EVLP allows both the evaluation of lungs outside of the donor and of the organ preservation through administration of therapeutic treatments. Recently, Tikkanen et al. demonstrated that EVLP is a safe and effective strategy for assessing high-risk donor lungs before LTx. Furthermore, they showed that with the use of EVLP, long-term survival, graft function, and improvements in quality were comparable to those of conventionally selected donor lungs [61]. Currently, although the EVLP technique has the potential to increase the number of usable lungs up to $30 \%[58,60]$, it is not routinely used in clinical practice for lungs accepted for standard donation; rather, it is considered a tool to allow for further evaluation of lungs that are deemed to be of low quality. However, there is growing evidence that EVLP could also serve for normally accepted lungs. EVLP can reduce ischemia-reperfusion injury (IRI), with the potential to improve organ quality and to reduce primary graft dysfunction (PGD) [62]. Interestingly, the idea of EVLP as a therapeutic platform to reduce inflammation, edema, and infection in allografts is very promising. For instance, in a swine model of DCD donor lungs, it has been shown that treatment with adenosine A2A receptor agonist during EVLP allows prolonged cold preservation of lungs [63]. Cypel et al. demonstrated that during EVLP, the delivery of an IL-10 gene with an adenoviral vector was able to improve lung function in injured human donor lungs [64]. Recently, Nakajima et al., in a swine model of IRI and EVLP, revealed that the administration of MSCs in donor lungs during EVLP ameliorated IRI both during perfusion and after transplantation [65]. In the next sections, we propose the therapeutic properties of MSCs as an important tool for the improvement of LTx by enhancing EVLP performance. 


\section{Mesenchymal Stromal/Stem Cells (MSCs) and Their Therapeutic Effects}

MSCs exist in adult tissues, such as fat [66], bone marrow (BM) [67], dental pulp (DP) [68], and neonatal tissues, including umbilical cord (UC) [69] and placenta tissue [70], where they participate in the maintenance of stem cell niches and tissue homoeostasis [71]. MSCs are mainly obtained from BM, though other sources such as neonatal tissues are commonly used to obtain MSCs from both umbilical cord and amniotic membrane [72-75]. In $\mathrm{BM}$, only 0.001 to $0.01 \%$ of the cells are MSCs [76]. Although a comparable number of MSCs can be found in neonatal tissue, this cell population shows better expandability in vitro, probably because of their fetal nature, as remarked by the expression of pluripotency markers and by a higher multilineage differentiation capacity $[73,75,77,78]$. Neonatal MSCs showed comparable regenerative effects to bone-marrow-derived MSCs (BM-MSCs) [73]. In addition, the use of neonatal-tissue-derived MSCs has some advantages such as being obtained easily in higher quantities without invasiveness, and being readily cultured to a sufficient number for their use.

\subsection{Biological Role of MSCs}

From a functional point of view, the scientific community presumes that MSCs belong to subsets of stem/progenitor cells in a specific microenvironment termed the "stem cells niche". In this case, these cells support tissue regeneration in both physiologic and pathologic conditions, contributing to tissue homeostasis [21,79-81]. MSCs are able to produce a plethora of trophic/regulator factors such as proteins and EXOs, and orchestrate individual components of the tissue microenvironment by differentiating or attracting supporting cells to a niche [21,79-82]. Moreover, numerous in vitro and in vivo studies have shown that MSCs are able to perform homing/migration and immunosuppression during pathophysiological processes [83-87]. For these reasons, MSC therapy has been extensively investigated to evaluate its therapeutic efficacy in degenerative and/or inflammatory diseases [88-92].

\subsection{Therapeutic Properties of MSCs}

The therapeutic properties of MSCs have been examined in both preclinical $[88,90]$ and clinical settings for the treatment of various disorders, including cardiovascular, neurodegenerative, immune, lung, liver, kidney and orthopedics diseases (clinicaltrials.gov). Due to low expression of CD40, CD80, CD86, and major histocompatibility complex I and II (MHC I/II) [93-95], MSCs are immuno-privileged; this feature make these cells a useful tool to be applied in the field of cell therapy.

MSCs possess immunomodulatory [84,96], trophic [97], angiogenic [98] and antioxidative properties [99], and all of these effects appear to be mediated, at least in part, by the production of a functional secretome. Indeed, in many in vitro and in vivo disease models, MSC-derived products have been identified as responsible for therapeutic effects [100]. These cells can produce many cytokines/chemokines controlling the immune system by interacting with both innate and adaptive responses, resulting in immunosuppression and the induction of tolerance [101]. It has been shown that MSCs secrete crucial anti- and proinflammatory factors (PGE2, Indoleamine 2,3-dioxygenase, TGF $\beta 1$, TSG-6, HGF, IL-10, IL-6, IFN $\gamma$, TNF- $\alpha$, LIF), which, depending on their ratio, regulate the pro- or anti-inflammatory activity of MSCs. In addition, final immunoregulatory properties may be influenced by cell culture conditions that can prime/enhance MSCs' properties [21,84,102-106].

MSCs also have the capacity to migrate to injured tissues, contributing to tissue repair/regeneration [107]. In this case, these cells put in place active regulation by producing paracrine components that impact on tissue survival, repair and regeneration, and also by activating tissue resident stem cells $[21,108,109]$. The secretion of numerous soluble factors has been considered responsible for the pro-angiogenic and anti-apoptotic effects of MSCs $[98,105]$. Apoptosis is known to occur during IRI, playing a crucial role in the IRI-dependent impairment of organ function [110]. It has been shown that injection of MSCs in a cardiomyopathic animal model decreases the level of apoptosis by increasing 
the Bcl-2/Bax ratio and inhibiting the level of activated caspase 3 [111]. CM derived from both BM-MSCs and adipose-derived MSCs (AdMSCs) was shown to be able to improve cell viability, to reduce the secretion of pro-inflammatory factors and to enhance IL-10 antiinflammatory cytokine production in hypoxic injured rat alveolar epithelial cells. These observed effects were due to the inhibition of p38 MAPK phosphorylation and the enhancement of Bcl-2 expression, promoting repair and cellular survival [43]. Moreover, it has been demonstrated that CM derived from human amnion-derived MSCs (AMSCs) was able to preserve the viability and delay apoptosis in A549 human alveolar epithelial cells, throughout the down-regulation of inflammatory factors and the upregulation of anti-apoptotic factors [41]. BM-MSC-derived CM supports lungs to attenuate ischemia by inhibiting pro-inflammatory cytokines [39], and AdMSC-derived CM protects the mouse liver from IRI [112]. An important functional component of MSC-derived CM is represented by EVs, such as EXOs. MSC-released EXOs can be transferred into the cells [113]. In this case, the transfer of functional biomolecules, including mRNAs, miRNAs and protein, can regulate/protect target cells [114,115]. It has been revealed that in an in vitro model, the suppression of T cells by MSCs was partly mediated via EVs [116], and that MSC-derived EXOs can transport miRNAs, showing an immunomodulatory capacity [84]. Also in an in vivo rat model, it has been shown that the injection of MSC-derived EVs protects the kidneys from IRI [117].

Oxidative stress is a pathological process common to cellular/tissue injury and inflammation, and is involved in many pathological processes including IRI [99]. Growing evidence derived from both in vitro and in vivo studies supports that MSCs can exert anti-oxidant properties by scavenging free radicals, promoting endogenous anti-oxidant defenses, altering mitochondrial bioenergetics, and donating functional mitochondria to damaged cells [99].

The above-mentioned properties may explain, at least in part, the cytoprotective and anti-inflammatory potential of MSCs. Overall, the multiple ability of MSCs to regulate many pathological processes offers a rationale for the use of MSCs as a promising therapeutic tool.

\section{Mesenchymal Stromal/Stem Cell (MSC)-based Therapeutic Approaches to Improving Lung Transplantation}

Survival rates after LTx have improved, yet outcomes are still poorer than other solid organ transplants [3,6]. The advances of the lung preservation techniques and the better understanding of the main mechanisms governing IRI processes can lead to a significant reduction in the incidence of lung PGD [118]. This condition is a type of acute lung injury that results from IRI and represents the major cause of early post-transplant morbidity and mortality [119]. In recent years, it has been shown that MSCs are able to reduce PGD. Jarvinen et al. showed that human lung resident MSCs have the potential to modulate immunological responses [120], and McAuley et al. revealed that MSCs can have the ability to restore alveolar fluid clearance in human lungs rejected after transplantation [32] Moreover, allogenic MSCs were able to reduce both acute lung injury (ALI) in an animal model and CLAD in human lung transplant recipients [121,122]. In fact, much scientific evidence has revealed the therapeutic properties of MSCs in different lung disease models [123-138], including those induced by IRI-related pathological processes. In Table 1 we summarized both in vitro and in vivo studies reporting the use of MSCs and/or their products in preventing lung injury/dysfunction. For LTx, there is a clinical need to implement new strategies for the prevention and treatment of IRI, and MSCs and/or their products represent a new therapeutic tool to prevent the occurrence of unwanted complications to further improve the success of LTx. 
Table 1. Summary of studies reporting the use of MSCs and/or their products in preventing lung injury.

\begin{tabular}{|c|c|c|c|c|}
\hline $\begin{array}{l}\text { Use of Cells or Their } \\
\text { Products }\end{array}$ & Study Model & $\begin{array}{l}\text { Effects Due to MSC } \\
\text { Treatment }\end{array}$ & Mechanisms & References \\
\hline BM-MSCs & Mouse lung IRI & $\begin{array}{l}\text { Protection against cold IRI } \\
\text { in lung transplants }\end{array}$ & $\begin{array}{l}\text { Improved arterial blood } \\
\text { oxygenation capacity, reduced } \\
\text { levels of pro-inflammatory } \\
\text { cytokine and cell apoptosis }\end{array}$ & [29] \\
\hline MSC-derived EVs & Rat lung IRI and EVLP & $\begin{array}{l}\text { Improved tissue integrity } \\
\text { and metabolism }\end{array}$ & $\begin{array}{l}\text { Decrease in vascular resistance } \\
\text { and rise in perfusate NO } \\
\text { metabolites; Up-regulation of } \\
\text { genes involved in the } \\
\text { resolution of both } \\
\text { inflammation and } \\
\text { oxidative stress }\end{array}$ & {$[34]$} \\
\hline $\begin{array}{l}\text { UC-MSCs and } \\
\text { UC-MSC-derived EVs }\end{array}$ & Mouse lung IRI & $\begin{array}{l}\text { Attenuation of lung } \\
\text { dysfunction and injury by } \\
\text { improving the efficacy of } \\
\text { EVLP }\end{array}$ & $\begin{array}{l}\text { Decreased levels of edema, } \\
\text { neutrophil infiltration and } \\
\text { myeloperoxidase; decrease in } \\
\text { pro-inflammatory cytokines } \\
\text { and increase in KGF, PGE2 and } \\
\text { IL-10; }\end{array}$ & [35] \\
\hline UC-MSC-derived EVs & $\begin{array}{l}\text { E. coli-induced rat lung } \\
\text { injury }\end{array}$ & Increased survival & $\begin{array}{l}\text { Enhanced phagocytosis of } E \text {. } \\
\text { coli }\end{array}$ & [36] \\
\hline $\begin{array}{l}\text { BM-MSCs and } \\
\text { BM-MSC-derived CM }\end{array}$ & Rat lung Injury & Attenuation of lung injury & $\begin{array}{l}\text { Reduced levels of } \\
\text { pro-inflammatory cytokine }\end{array}$ & [37] \\
\hline $\begin{array}{l}\text { BM-MSCs and } \\
\text { BM-MSC-derived CM }\end{array}$ & $\begin{array}{l}\text { Ventilator-induced rat } \\
\text { lung injury }\end{array}$ & $\begin{array}{l}\text { Reduction in injury and } \\
\text { improvement in recovery }\end{array}$ & $\begin{array}{l}\text { Reduced levels of edema, } \\
\text { neutrophil, and alveolar IL-6 } \\
\text { concentrations }\end{array}$ & {$[38]$} \\
\hline BM-MSC-derived CM & Rat lung IRI & Protection against lung IRI & $\begin{array}{l}\text { Decrease in both } \\
\text { pro-inflammatory cytokines } \\
\text { and infiltrating inflammatory } \\
\text { cells, and increase in both } \\
\text { M2-like macrophages and } \\
\text { regulatory T cells }\end{array}$ & [39] \\
\hline AdMSC-derived CM & $\begin{array}{l}\text { LPS-induced mouse } \\
\text { lung injury }\end{array}$ & Reduction in ARDS indices & $\begin{array}{l}\text { Reduced endothelial barrier } \\
\text { hyperpermeability and } \\
\text { activation of pro-inflammatory } \\
\text { and pro-apoptotic pathways in } \\
\text { endothelium. }\end{array}$ & [40] \\
\hline AMSC-derived CM & $\begin{array}{l}\text { In vitro model of } \\
\text { human lung IRI }\end{array}$ & $\begin{array}{l}\text { Attenuation of IRI effects } \\
\text { by improving the efficacy } \\
\text { of in vitro EVLP }\end{array}$ & $\begin{array}{l}\text { Increase in anti-inflammatory } \\
\text { factors and up-regulation of } \\
\text { anti-apoptotic factors }\end{array}$ & [41] \\
\hline $\begin{array}{l}\text { BM-MSCs and } \\
\text { AdMSC-derived CM }\end{array}$ & $\begin{array}{l}\text { Rat and human } \\
\text { alveolar epithelial cell } \\
\text { injury }\end{array}$ & Decreased cell injury & $\begin{array}{l}\text { Decrease in pro-inflammatory } \\
\text { factors and increase in } \\
\text { anti-inflammatory factors; } \\
\text { inhibition of p38 MAPK and } \\
\text { translocation of Bcl-2 to the } \\
\text { nucleus; Increased expression } \\
\text { of cytoprotective } \\
\text { glucose-regulated proteins }\end{array}$ & [43] \\
\hline MSCs & Swine lung IRI & $\begin{array}{l}\text { Attenuation of ischemic } \\
\text { injury in donor lungs } \\
\text { during EVLP and } \\
\text { attenuation of IRI after } \\
\text { transplantation }\end{array}$ & $\begin{array}{l}\text { Increased levels of HGF and } \\
\text { IL- } 4 \text { and decreased levels of } \\
\text { TNF } \alpha \text { and cell death markers }\end{array}$ & [65] \\
\hline BM-MSCs & $\begin{array}{l}\text { HCL- and LPS-induced } \\
\text { rat lung injury }\end{array}$ & Decreased inflammation & $\begin{array}{l}\text { Decrease in proinflammatory } \\
\text { cytokines, } \\
\text { neutrophil infiltration, } \\
\text { hemorrhage and } \\
\text { interstitial edema }\end{array}$ & [122] \\
\hline
\end{tabular}


Table 1. Cont.

\begin{tabular}{|c|c|c|c|c|}
\hline $\begin{array}{l}\text { Use of Cells or Their } \\
\text { Products }\end{array}$ & Study Model & $\begin{array}{l}\text { Effects Due to MSC } \\
\text { Treatment }\end{array}$ & Mechanisms & References \\
\hline $\begin{array}{l}\text { UC-MSCs and } \\
\text { UC-MSC-derived EVs }\end{array}$ & $\begin{array}{l}\text { Rat neonatal hyperoxic } \\
\text { lung injuries }\end{array}$ & $\begin{array}{l}\text { Attenuation of hyperoxic } \\
\text { lung injuries }\end{array}$ & $\begin{array}{l}\text { Increased alveolarization and } \\
\text { angiogenesis; decrease in } \\
\text { alveolar epithelial cell death, } \\
\text { macrophages and cytokines } \\
\text { in lung }\end{array}$ & [123] \\
\hline BM-MSC-derived EVs & $\begin{array}{l}\text { Mouse pulmonary } \\
\text { arterial hypertension }\end{array}$ & $\begin{array}{l}\text { Reduction in pulmonary } \\
\text { vascular remodeling and } \\
\text { right ventricle hypertrophy }\end{array}$ & $\begin{array}{l}\text { Increased levels of } \\
\text { anti-inflammatory and } \\
\text { anti-proliferative miRs } \\
\text { including miRs-34a,-122,-124, } \\
\text { and -127. }\end{array}$ & [124] \\
\hline BM-MSCs & Rat lung IRI & $\begin{array}{l}\text { Attenuation of lung } \\
\text { pathologic injury }\end{array}$ & $\begin{array}{l}\text { Reduced myeloperoxidase } \\
\text { production, decreased levels of } \\
\text { of pro-inflammatory cytokine } \\
\text { and cell apoptosis in } \\
\text { lung tissue }\end{array}$ & [125] \\
\hline BM-MSCs & $\begin{array}{l}\text { E. coli-induced rat } \\
\text { pneumonia }\end{array}$ & $\begin{array}{l}\text { Reduction in lung injury; } \\
\text { improvement in survival; } \\
\text { reduction in lung bacterial } \\
\text { load and suppression of } \\
\text { inflammation }\end{array}$ & $\begin{array}{l}\text { Enhanced macrophage } \\
\text { phagocytic capacity and } \\
\text { increase in lung and systemic } \\
\text { concentrations of the } \\
\text { antimicrobial peptide LL37 }\end{array}$ & [126] \\
\hline BM-MSCs & $\begin{array}{l}\text { Hyperoxia-induced rat } \\
\text { lung injury }\end{array}$ & Mitigation of emphysema & $\begin{array}{l}\text { Increased number of alveoli } \\
\text { and decrease in } \alpha \text {-SMA } \\
\text { expression by myofibroblasts }\end{array}$ & [127] \\
\hline $\begin{array}{l}\text { BM-MSCs and } \\
\text { BM-MSC-derived CM }\end{array}$ & $\begin{array}{l}\text { Cigarette-smoke- } \\
\text { induced rat } \\
\text { emphysema }\end{array}$ & $\begin{array}{l}\text { Alleviation of emphysema } \\
\text { and increase in the number } \\
\text { of small pulmonary vessels }\end{array}$ & $\begin{array}{l}\text { Decrease in pulmonary artery } \\
\text { medial wall thickness and } \\
\text { reduction in apoptosis in lungs } \\
\text { with emphysema }\end{array}$ & [128] \\
\hline $\begin{array}{l}\text { BM-MSCs and } \\
\text { BM-MSC-derived CM }\end{array}$ & $\begin{array}{l}\text { LPS-induced mouse } \\
\text { lung injury }\end{array}$ & $\begin{array}{l}\text { Resolution of lung injury } \\
\text { by attenuating lung } \\
\text { inflammation }\end{array}$ & $\begin{array}{l}\text { Decrease in neutrophils and } \\
\text { increase in } \mathrm{M} 2 \text { in BAL }\end{array}$ & [129] \\
\hline $\begin{array}{l}\text { BM-MSCs and } \\
\text { BM-MSC-derived CM }\end{array}$ & $\begin{array}{l}\text { Mouse chronic } \\
\text { obstructive pulmonary } \\
\text { disease }\end{array}$ & Reduction in injury & $\begin{array}{l}\text { Reduced levels of } \\
\text { inflammation, fibrosis and } \\
\text { apoptotic and increased } \\
\text { production of HGF }\end{array}$ & [130] \\
\hline AdMSC-derived EVs & $\begin{array}{l}\text { Elastase-induced } \\
\text { mouse emphysema }\end{array}$ & $\begin{array}{l}\text { Reduction in lung } \\
\text { emphysema }\end{array}$ & Increased levels of FGF2 & [131] \\
\hline BM-MSCs & $\begin{array}{l}\text { Bleomycin-induced rat } \\
\text { pulmonary fibrosis }\end{array}$ & Decreased fibrosis & $\begin{array}{l}\text { Attenuation of NRF2, NQO1, } \\
\text { HO- } 1, \gamma-G C S, \text { lipid } \\
\text { peroxidation, and increase in } \\
\text { SOD activity }\end{array}$ & [132] \\
\hline UC-MSCs & Rat lung IRI & $\begin{array}{l}\text { Reduction in Oxidative } \\
\text { stress damage and } \\
\text { inflammation }\end{array}$ & $\begin{array}{l}\text { Reduced levels of MPO } \\
\text { activity and neutrophil } \\
\text { markers; reduction in reactive } \\
\text { oxygen species production }\end{array}$ & [133] \\
\hline $\begin{array}{l}\text { AdMSCs and } \\
\text { AdMSC-derived CM }\end{array}$ & $\begin{array}{l}\text { Sulfur } \\
\text { mustard-induced } \\
\text { mouse lung injury }\end{array}$ & $\begin{array}{l}\text { Reduction in progressive } \\
\text { histopathologic changes in } \\
\text { the lung }\end{array}$ & $\begin{array}{l}\text { Reducd levels of both M1 and } \\
\text { M2 cells, TNF- } \alpha \text { and IL- } 1 \beta\end{array}$ & [134] \\
\hline BM-MSC-derived CM & $\begin{array}{l}\text { Bleomycin-induced rat } \\
\text { pulmonary fibrosis }\end{array}$ & $\begin{array}{l}\text { Protection against lung } \\
\text { fibrosis }\end{array}$ & $\begin{array}{l}\text { Decrease in lung inflammation, } \\
\text { fibrotic scores, collagen } \\
\text { deposition, and cell apoptosis } \\
\text { Reduced levels of }\end{array}$ & [135] \\
\hline $\begin{array}{l}\text { SHEDs and } \\
\text { SHED-derived CM }\end{array}$ & $\begin{array}{l}\text { Bleomycin-induced } \\
\text { mouse pulmonary } \\
\text { fibrosis }\end{array}$ & $\begin{array}{l}\text { Attenuation of lung injury } \\
\text { and improvement in } \\
\text { survival rate }\end{array}$ & $\begin{array}{l}\text { Reduced levels of } \\
\text { pro-inflammatory factors and } \\
\text { increased levels of } \\
\text { anti-inflammatory factors and } \\
\text { M2 cells }\end{array}$ & [136] \\
\hline BM-MSCs & $\begin{array}{l}\text { Swine lung } \\
\text { transplantation }\end{array}$ & $\begin{array}{l}\text { Improvement in dynamic } \\
\text { lung compliance }\end{array}$ & $\begin{array}{l}\text { Reduced } \\
\text { intrapulmonary edema }\end{array}$ & [137] \\
\hline
\end{tabular}


Table 1. Cont.

\begin{tabular}{|c|c|c|c|c|}
\hline $\begin{array}{l}\text { Use of Cells or Their } \\
\text { Products }\end{array}$ & Study Model & $\begin{array}{l}\text { Effects Due to MSC } \\
\text { Treatment }\end{array}$ & Mechanisms & References \\
\hline BM-MSC-derived EVs & $\begin{array}{l}\text { E. Coli-induced mouse } \\
\text { lung Injury }\end{array}$ & $\begin{array}{l}\text { Reduction in lung edema } \\
\text { and inflammation }\end{array}$ & $\begin{array}{l}\text { Decrease in lung protein } \\
\text { permeability, neutrophils and } \\
\text { macrophage inflammatory } \\
\text { protein-2 levels in the BAL } \\
\text { fluid; increase in KGF in BAL }\end{array}$ & [138] \\
\hline AdMSCs & Rat lung IRI & $\begin{array}{l}\text { Attenuation of lung } \\
\text { damage after IRI }\end{array}$ & $\begin{array}{l}\text { Suppression of oxidative stress } \\
\text { and inflammatory reaction }\end{array}$ & [139] \\
\hline UC-MSCs & Swine lung IRI & $\begin{array}{l}\text { Attenuation of IRI by } \\
\text { improving the efficacy of } \\
\text { EVLP }\end{array}$ & $\begin{array}{l}\text { Increased levels of VEGF and } \\
\text { decreased concentration of } \\
\text { circulating IL-8 }\end{array}$ & [140] \\
\hline BM-MSCs & $\begin{array}{l}\text { Human lung IRI } \\
\text { and EVLP }\end{array}$ & $\begin{array}{l}\text { Decreased cold ischemic } \\
\text { injury }\end{array}$ & $\begin{array}{l}\text { Decrease in pro-inflammatory } \\
\text { cytokines and increase in } \\
\text { anti-inflammatory cytokines }\end{array}$ & [30] \\
\hline $\begin{array}{l}\text { BM-MSCs and } \\
\text { BM-MSC-derived CM }\end{array}$ & $\begin{array}{l}\text { E. coli-induced human } \\
\text { lung injury }\end{array}$ & $\begin{array}{l}\text { Increase in alveolar fluid } \\
\text { clearance in lungs during } \\
\text { EVLP }\end{array}$ & KGF secretion & [31] \\
\hline BM-MSCs & $\begin{array}{l}\text { Human lungs rejected } \\
\text { for transplantation and } \\
\text { subjected to prolonged } \\
\text { ischemic time }\end{array}$ & $\begin{array}{l}\text { Restoration of alveolar } \\
\text { fluid clearance }\end{array}$ & KGF secretion & [32] \\
\hline BM-MSC-derived EVs & $\begin{array}{l}\text { Human lungs rejected } \\
\text { for transplantation }\end{array}$ & $\begin{array}{l}\text { Increase in alveolar fluid } \\
\text { clearance in donor lungs } \\
\text { during EVLP }\end{array}$ & $\begin{array}{l}\text { Improved airway and } \\
\text { hemodynamic parameters }\end{array}$ & [141] \\
\hline AdMSCs & Clinical trial & $\begin{array}{l}\text { Attenuation of IRI and host } \\
\text { immunological reaction } \\
\text { towards the graft }\end{array}$ & Not determined & NCT04714801 \\
\hline BM-MSCs & Clinical trial & $\begin{array}{l}\text { Attenuation of graft } \\
\text { rejection and bronchiolitis } \\
\text { obliteran syndrome (BOS) }\end{array}$ & Not determined & NCT02181712 \\
\hline
\end{tabular}

MSCs: mesenchymal stromal/stem cells; BM-MSCs: bone-marrow-derived MSCs; AMSCs: amnion-derived MSCs; UC-MSCs: umbilical-cord-derived MSCs; AdMSCs: adipose-derived MSCs; SHEDs: stromal/stem cells from human exfoliated deciduous teeth; IRI: ischemia-reperfusion injury; EVLP: ex vivo lung perfusion; CM: conditioned medium; EVs: extracellular vesicles; BAL: bronchoalveolar lavage; ARDS: acute respiratory distress syndrome.

\subsection{Therapeutic Effects of MSCs on Ischemia-Reperfusion Injury (IRI)}

Ischemia-reperfusion injury events can occur in the case of stroke or myocardial infarction, as well as in solid organ transplantation. Prolonged ischemia causes deprivation of both oxygen and nutrients, leading to cellular metabolic and ultrastructural pathological changes [142]. Pathological effects mediated by IRI are often potentiated by the onset of inflammation processes, affecting organ quality and transplant outcomes in solid organ transplantation [143]. In this case, IRI-associated injury can be attenuated by cold ischemia storage, but it cannot be completely prevented [144]. Moreover, oxidative stress is a crucial process of IRI-associated effects, leading to the production of toxic molecules [142]. Much scientific evidence shows that MSCs have been able to decrease inflammation and IRI in both in vitro and in vivo models, and these effects are mediated by different mechanisms, including paracrine activity producing a functional secretome [145]. It has been shown that AdMSCs were able to reduce myocardial IRI and to decrease pro-inflammatory cytokine in an in vivo mouse model [146]. In an IRI rat model, Cui et al. demonstrated that AdMSCderived EXOs were able to protect the myocardium [147]. Using a rat model of acute renal failure, Mias et al. demonstrated that an injection of BM-MSCs protected the kidneys from IRI, and this effect was enhanced when the cells were primed with melatonin. That result appears to be mediated, at least in part, by the production of soluble factors such as b-FGF and HGF [148]. Additionally, in liver IRI models, some therapeutic effects of MSCs can be attributed to soluble factors. Indeed, in a mouse model of liver IRI, it has been shown 
that the injection of BM-MSC-derived EVs decreased both inflammation and IRI, also reducing cell apoptotic levels and the production of ROS [149]. In a different in vivo model of liver IRI, an injection of BM-MSCs ameliorated hepatic IRI by reducing inflammation and liver apoptosis, and by increasing antioxidant proteins [150,151]. Beneficial effects of MSC treatments were also showed in different lung IRI models. Sun et al. revealed that the autologous transplantation of AdMSCs reduced ischemia-reperfusion lung injury in a rodent model [139]. Lu et al., in a rat model of lung IRI, showed that an intravenous injection of BM-MSCs reduced both pulmonary edema and pro-inflammatory factors, while increasing anti-inflammatory factors [152]. Moreover, MSC therapy may reduce acute IRI and fibrotic responses in human lungs rejected for transplantation, preventing the severity of PGD [32].

\subsection{MSCs as Therapeutic Tool to Improve EVLP}

Focusing on expanding the donor pool to reduce the mortality of lung transplant in recipient patients, different approaches are currently being explored, including the extended criteria for the selection of donors [153], and lung procurement from donors after cardiac death [3]. These strategies have led to the use of the so-called "marginal" organs that do not fulfill the standard criteria of donor lungs. For this scenario, the ex vivo lung perfusion (EVLP) technique was developed in order to: 1. assess graft function after procurement and before implantation; 2. preserve the graft after harvesting; and 3. repair/regenerate potential grafts previously considered unsuitable for transplantation [17,154]. In a lungtransplanted rat model, EVLP treatment was able to protect lung tissue against IRI side effects [155] and, to further reduce IRI complications, pharmacological treatments are possible either by intravascular or endobronchial administration [15,16]. Moreover, although the molecular mechanisms underpinning lung regeneration during EVLP have not been explored yet, recent studies have analyzed metabolic/proteomic events to reveal potential regenerative effects of EVLP [156,157]. This may offer an additional opportunity to evaluate both questionable donor lungs and the effectiveness of new treatments.

In recent years, promising advances in the field of MSC therapy have been made, and the use of MSCs has also become a potential clinical tool to treat complex lung diseases [158]. MSCs can secrete crucial paracrine factors that regulate endothelial/epithelial permeability, attenuate inflammation and potentiate anti-microbial action in lungs [141,159]. These characteristics, together with the fact that MSCs possess anti-oxidant properties [99], have led researchers to investigate biological treatments based on the use of MSCs and/or their products also in the field of lung transplantation. In particular, MSC-based treatments have been tested to improve EVLP and, while some studies have directly used MSCs, similar results have been achieved using MSC-derived products such as EVs and CM. La Francesca et al. showed that BM-MSCs were able to decrease cold ischemic injury in ex vivo perfused donor lungs. In particular, in this pilot study, two effects were observed: a significant reduction in pro-inflammatory cytokines, and an increase in anti-inflammatory cytokines in non-transplantable human lungs [30]. Mordant et al. showed that, in a swine lung IRI model, UC-MSC treatment administered during EVLP was able to attenuate IRI by improving the efficacy of EVLP. This effect appears to be attributable to increased levels of VEGF and a decreased concentration of circulating IL-8 [140]. In a similar study model, Nakajima et al. showed that MSCs were able to attenuate ischemic injury in donor lungs both during EVLP and after transplantation. In this case, the observed effects appear to be ascribed to both the increase in HGF and IL-4, and the decrease in TNF $\alpha$ and cell-death markers [65]. On the other hand, Lonati at al., in a rat lung IRI model, used MSC-derived EVs administered during EVLP, showing that this product was able to improve lung tissue integrity, decreasing the vascular resistance and up-regulating crucial genes involved in the resolution of both inflammation and oxidative stress [34]. Miceli et al., in an in vitro model of human lung IRI and EVLP, showed that AMSC-derived CM was able to attenuate IRI effects by improving the efficacy of EVLP, increasing anti-inflammatory factors and up-regulating anti-apoptotic factors [41]. Gennai et al. showed that BM-MSC-derived 
EVs were able to increase the alveolar fluid clearance in human donor lungs rejected for transplantation and perfused with EVLP [141]. Moreover, both BM-MSCs and BM-MSCderived $\mathrm{CM}$, when administered during EVLP, were able to increase alveolar fluid clearance in human lung injured by E. coli endotoxin [31]. UC-MSCs and UC-MSC-derived EVs, in a mouse lung IRI model, were able to attenuate lung dysfunction and injury by improving the efficacy of EVLP, and these effects were attributable to a decrease in edema, neutrophil infiltration, and pro-inflammatory cytokines, and increase in KGF, PGE2 and IL-10 [35].

Therefore, the overall data show that the role of MSCs in improving lung recovery appears to be mediated mainly by MSC paracrine signaling; furthermore, the use of MSCs and/or their products, including EVs and CM, represents a promising approach to improving EVLP reconditioning of transplanted lungs. Because of MSCs ability to secrete paracrine factors with anti-inflammatory, anti-oxidant and anti-apoptotic properties, MSCs and/or their products represent a useful tool for integration with EVLP to further preserve/regenerate lung tissue by attenuating IRI during LTx (Figure 1).
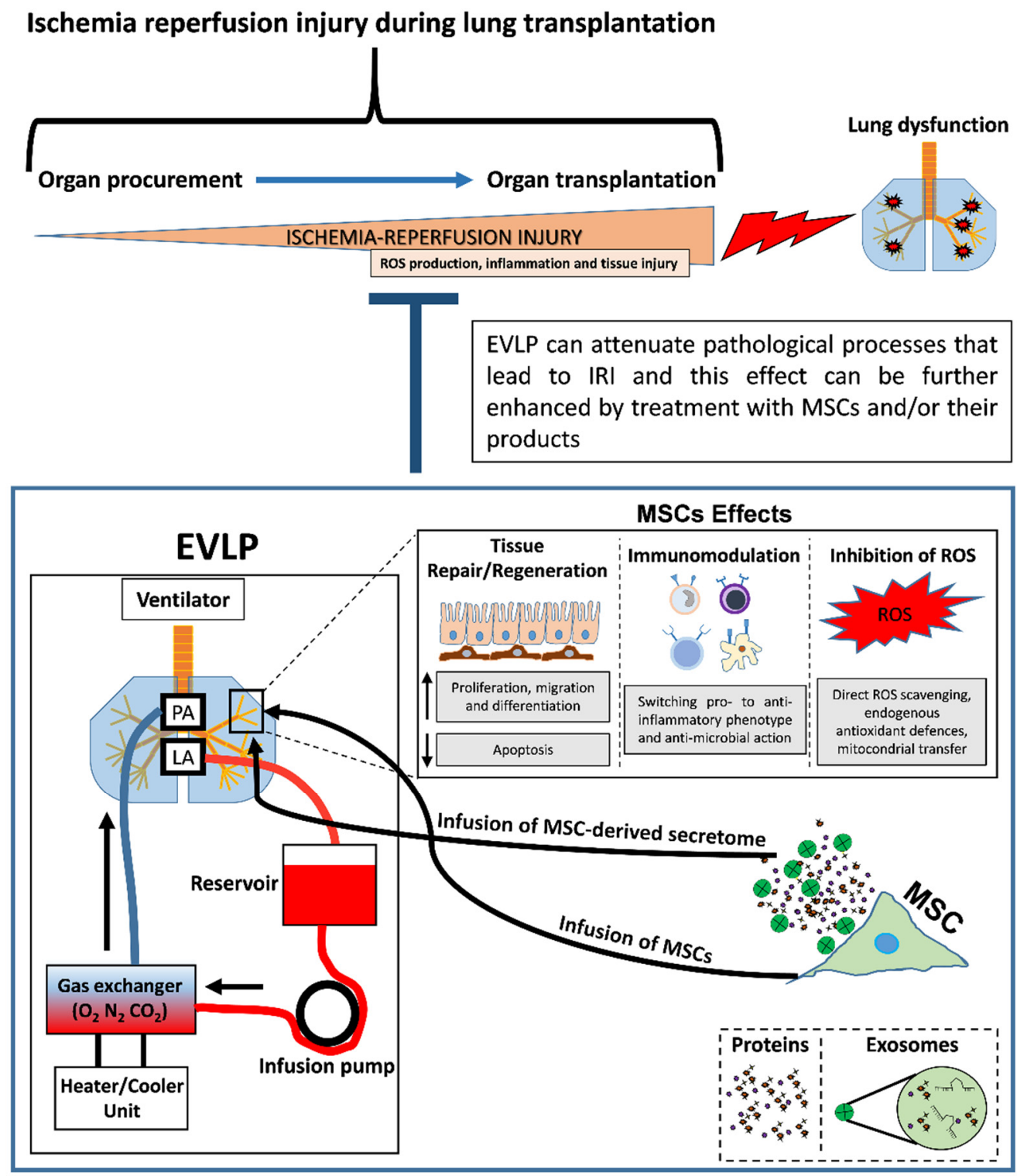

Figure 1. Therapeutic strategies to improve ex vivo lung perfusion (EVLP) during lung transplantation. EVLP treatment may sometimes be not sufficient to mitigate ischemia-reperfusion injury (IRI) effects, and lung graft can reveal the lung to have a poor quality after transplantation. The treatment with mesenchymal stromal/stem cells (MSCs) and/or their products (conditioned medium and/or 
exosomes containing growth factors, cytokines and chemokines) can effectively potentiate EVLP performance and attenuate IRI adverse events by inducing: 1. tissue repair/regeneration; 2 . inhibition of reactive oxygen species (ROS); 3 . immunomodulation. These effects can lead to the improvement of clinical outcomes after lung transplantation.

\section{Conclusions and Perspectives}

Many preclinical studies in animal models have clearly shown that the therapeutic effects of MSCs on lung injury, and specifically on ischemia-reperfusion injury after LTx, are mediated by the reduction in inflammation [26-29,34-37,39,40,65,125,129,137,140]. Moreover, in a preclinical setting, it has also been demonstrated that MSCs have been able to protect human lungs during transplantation [30-32,141]. Interestingly, these effects appear to be related, at least in part, to the paracrine secretion of MSC factors, including proteins and EVs (such as EXOs), which offer an opportunity to develop new cell-free treatments for human lung diseases. On the other hand, only two clinical studies (clinicaltrial.gov, NCT number: NCT04714801 and NCT02181712) are currently testing the potential role of MSC therapy in lung transplantation to avoid graft rejection. Therefore, although many works have shown the potential application of MSCs in improving the outcomes of lung transplantation, these effects have not been confirmed in appropriate clinical studies yet. Several issues can explain the limited use of MSCs in this field. In our opinion, there are still relevant limitations to the use of MSC therapy in lung transplant clinical practice. MSCs display mutable properties related to the biological and technical variability of their preparation, and these may impact on the therapeutic potency of MSCs $[21,88,95]$. In particular, the optimal source, dose, and priming of MSCs is crucial and should be optimized. The best EVLP strategy and protocols to treat lungs before transplantation still need to be elucidated. In addition, another important aspect to be clarified is whether the use of MSC-derived products, such as secretome and/or EXOs, can offer additional benefits compared to standard preparations. The understanding of these critical issues could allow the introduction of MSC treatments in clinical lung transplantation. More efficacy studies-for example, in large animals - are needed to determine the best approach for a human clinical setting. Further investigation is needed to better integrate MSC therapy with EVLP use. This new strategy can lead to enhanced EVLP performance, with the ultimate goal of increasing the number of donor lungs and their quality. Moreover, the routine use of EVLP in clinical practice can favor an improvement in lung transplant management and outcomes.

Author Contributions: Conceptualization, V.M. and A.B.; writing-original draft preparation, V.M. and A.B.; writing-review and editing, V.M. and A.B. All authors have read and agreed to the published version of the manuscript.

Funding: This research received no external funding.

Conflicts of Interest: The authors declare no conflict of interest.

\section{References}

1. $\quad$ van der Mark, S.C.; Hoek, R.A.S.; Hellemons, M.E. Developments in lung transplantation over the past decade. Eur. Respir Rev. 2020, 29, 190132. [CrossRef] [PubMed]

2. Forgie, K.A.; Fialka, N.; Freed, D.H.; Nagendran, J. Lung Transplantation, Pulmonary Endothelial Inflammation, and Ex-Situ Lung Perfusion: A Review. Cells 2021, 10, 1417. [CrossRef] [PubMed]

3. Keshavamurthy, S.; Rodgers-Fischl, P. Donation after circulatory death (DCD)-lung procurement. Indian. J. Thorac. Cardiovasc. Surg. 2021, 37, 425-432. [CrossRef] [PubMed]

4. Opelz, G.; Dohler, B.; Ruhenstroth, A.; Cinca, S.; Unterrainer, C.; Stricker, L.; Scherer, S.; Gombos, P.; Susal, C.; Daniel, V.; et al. The collaborative transplant study registry. Transpl. Rev. (Orlando). 2013, 27, 43-45. [CrossRef]

5. Shepherd, H.M.; Gauthier, J.M.; Puri, V.; Kreisel, D.; Nava, R.G. Advanced considerations in organ donors. J. Thorac Dis. 2021, 13, 6528-6535. [CrossRef]

6. Thabut, G.; Mal, H. Outcomes after lung transplantation. J. Thorac Dis. 2017, 9, 2684-2691. [CrossRef] 
7. Gagliotti, C.; Morsillo, F.; Moro, M.L.; Masiero, L.; Procaccio, F.; Vespasiano, F.; Pantosti, A.; Monaco, M.; Errico, G.; Ricci, A.; et al. Infections in liver and lung transplant recipients: A national prospective cohort. Eur. J. Clin. Microbiol. Infect. Dis. 2018, 37, 399-407. [CrossRef]

8. Sun, H.; Deng, M.; Chen, W.; Liu, M.; Dai, H.; Wang, C. Graft dysfunction and rejection of lung transplant, a review on diagnosis and management. Clin. Respir. J. 2022, 16, 5-12. [CrossRef]

9. Bozso, S.; Vasanthan, V.; Luc, J.G.; Kinaschuk, K.; Freed, D.; Nagendran, J. Lung transplantation from donors after circulatory death using portable ex vivo lung perfusion. Can. Respir. J. 2015, 22, 47-51. [CrossRef]

10. Laubach, V.E.; Sharma, A.K. Mechanisms of lung ischemia-reperfusion injury. Curr. Opin. Organ. Transplant. 2016, 21, 246-252. [CrossRef]

11. de Perrot, M.; Liu, M.; Waddell, T.K.; Keshavjee, S. Ischemia-reperfusion-induced lung injury. Am. J. Respir. Crit. Care Med. 2003, 167, 490-511. [CrossRef]

12. Kawashima, M.; Juvet, S.C. The role of innate immunity in the long-term outcome of lung transplantation. Ann. Transl. Med. 2020, 8, 412. [CrossRef] [PubMed]

13. Charles, E.J.; Huerter, M.E.; Wagner, C.E.; Sharma, A.K.; Zhao, Y.; Stoler, M.H.; Mehaffey, J.H.; Isbell, J.M.; Lau, C.L.; Tribble, C.G.; et al. Donation After Circulatory Death Lungs Transplantable Up to Six Hours After Ex Vivo Lung Perfusion. Ann. Thorac. Surg. 2016, 102, 1845-1853. [CrossRef] [PubMed]

14. Cypel, M.; Yeung, J.C.; Machuca, T.; Chen, M.; Singer, L.G.; Yasufuku, K.; de Perrot, M.; Pierre, A.; Waddell, T.K.; Keshavjee, S. Experience with the first 50 ex vivo lung perfusions in clinical transplantation. J. Thorac. Cardiovasc. Surg. 2012, 144, $1200-1206$. [CrossRef]

15. Huerter, M.E.; Sharma, A.K.; Zhao, Y.; Charles, E.J.; Kron, I.L.; Laubach, V.E. Attenuation of Pulmonary Ischemia-Reperfusion Injury by Adenosine A2B Receptor Antagonism. Ann. Thorac. Surg. 2016, 102, 385-393. [CrossRef] [PubMed]

16. Martens, A.; Boada, M.; Vanaudenaerde, B.M.; Verleden, S.E.; Vos, R.; Verleden, G.M.; Verbeken, E.K.; Van Raemdonck, D.; Schols, D.; Claes, S.; et al. Steroids can reduce warm ischemic reperfusion injury in a porcine donation after circulatory death model with ex vivo lung perfusion evaluation. Transpl. Int. 2016, 29, 1237-1246. [CrossRef]

17. Nakajima, D.; Date, H. Ex vivo lung perfusion in lung transplantation. Gen. Thorac. Cardiovasc. Surg. 2021, 69, 625-630. [CrossRef] [PubMed]

18. Gallo, A.; Cuscino, N.; Contino, F.; Bulati, M.; Pampalone, M.; Amico, G.; Zito, G.; Carcione, C.; Centi, C.; Bertani, A.; et al. Changes in the Transcriptome Profiles of Human Amnion-Derived Mesenchymal Stromal/Stem Cells Induced by Three-Dimensional Culture: A Potential Priming Strategy to Improve Their Properties. Int. J. Mol. Sci. 2022, 23, 863. [CrossRef]

19. Konala, V.B.; Mamidi, M.K.; Bhonde, R.; Das, A.K.; Pochampally, R.; Pal, R. The current landscape of the mesenchymal stromal cell secretome: A new paradigm for cell-free regeneration. Cytotherapy 2016, 18, 13-24. [CrossRef]

20. Lo Nigro, A.; Gallo, A.; Bulati, M.; Vitale, G.; Paini, D.S.; Pampalone, M.; Galvagno, D.; Conaldi, P.G.; Miceli, V. Amnion-Derived Mesenchymal Stromal/Stem Cell Paracrine Signals Potentiate Human Liver Organoid Differentiation: Translational Implications for Liver Regeneration. Front. Med. (Lausanne) 2021, 8, 746298. [CrossRef]

21. Miceli, V.; Bulati, M.; Iannolo, G.; Zito, G.; Gallo, A.; Conaldi, P.G. Therapeutic Properties of Mesenchymal Stromal/Stem Cells: The Need of Cell Priming for Cell-Free Therapies in Regenerative Medicine. Int. J. Mol. Sci. 2021, 22, 763. [CrossRef]

22. Jimenez-Puerta, G.J.; Marchal, J.A.; Lopez-Ruiz, E.; Galvez-Martin, P. Role of Mesenchymal Stromal Cells as Therapeutic Agents: Potential Mechanisms of Action and Implications in Their Clinical Use. J. Clin. Med. 2020, 9, 445. [CrossRef] [PubMed]

23. Madrigal, M.; Rao, K.S.; Riordan, N.H. A review of therapeutic effects of mesenchymal stem cell secretions and induction of secretory modification by different culture methods. J. Transl. Med. 2014, 12, 260. [CrossRef]

24. Mohammadipoor, A.; Antebi, B.; Batchinsky, A.I.; Cancio, L.C. Therapeutic potential of products derived from mesenchymal stem/stromal cells in pulmonary disease. Respir. Res. 2018, 19, 218. [CrossRef]

25. Wick, K.D.; Leligdowicz, A.; Zhuo, H.; Ware, L.B.; Matthay, M.A. Mesenchymal stromal cells reduce evidence of lung injury in patients with ARDS. JCI Insight 2021, 6, e148983. [CrossRef] [PubMed]

26. Abreu, S.C.; Weiss, D.J.; Rocco, P.R. Extracellular vesicles derived from mesenchymal stromal cells: A therapeutic option in respiratory diseases? Stem Cell Res. Ther. 2016, 7, 53. [CrossRef] [PubMed]

27. Morrison, T.J.; Jackson, M.V.; Cunningham, E.K.; Kissenpfennig, A.; McAuley, D.F.; O'Kane, C.M.; Krasnodembskaya, A.D. Mesenchymal Stromal Cells Modulate Macrophages in Clinically Relevant Lung Injury Models by Extracellular Vesicle Mitochondrial Transfer. Am. J. Respir. Crit. Care Med. 2017, 196, 1275-1286. [CrossRef] [PubMed]

28. Schmelzer, E.; Miceli, V.; Chinnici, C.M.; Bertani, A.; Gerlach, J.C. Effects of Mesenchymal Stem Cell Coculture on Human Lung Small Airway Epithelial Cells. BioMed Res. Int. 2020, 2020, 9847579. [CrossRef]

29. Tian, W.; Liu, Y.; Zhang, B.; Dai, X.; Li, G.; Li, X.; Zhang, Z.; Du, C.; Wang, H. Infusion of mesenchymal stem cells protects lung transplants from cold ischemia-reperfusion injury in mice. Lung 2015, 193, 85-95. [CrossRef]

30. La Francesca, S.; Ting, A.E.; Sakamoto, J.; Rhudy, J.; Bonenfant, N.R.; Borg, Z.D.; Cruz, F.F.; Goodwin, M.; Lehman, N.A.; Taggart J.M.; et al. Multipotent adult progenitor cells decrease cold ischemic injury in ex vivo perfused human lungs: An initial pilot and feasibility study. Transplant. Res. 2014, 3, 19. [CrossRef]

31. Lee, J.W.; Fang, X.; Gupta, N.; Serikov, V.; Matthay, M.A. Allogeneic human mesenchymal stem cells for treatment of E. coli endotoxin-induced acute lung injury in the ex vivo perfused human lung. Proc. Natl. Acad. Sci. USA 2009, 106, 16357-16362. [CrossRef] [PubMed] 
32. McAuley, D.F.; Curley, G.F.; Hamid, U.I.; Laffey, J.G.; Abbott, J.; McKenna, D.H.; Fang, X.; Matthay, M.A.; Lee, J.W. Clinical grade allogeneic human mesenchymal stem cells restore alveolar fluid clearance in human lungs rejected for transplantation. Am. J. Physiol. Lung Cell Mol. Physiol. 2014, 306, L809-L815. [CrossRef]

33. Ullah, M.; Kodam, S.P.; Mu, Q.; Akbar, A. Microbubbles versus Extracellular Vesicles as Therapeutic Cargo for Targeting Drug Delivery. ACS Nano 2021, 15, 3612-3620. [CrossRef] [PubMed]

34. Lonati, C.; Bassani, G.A.; Brambilla, D.; Leonardi, P.; Carlin, A.; Maggioni, M.; Zanella, A.; Dondossola, D.; Fonsato, V.; Grange, C.; et al. Mesenchymal stem cell-derived extracellular vesicles improve the molecular phenotype of isolated rat lungs during ischemia/reperfusion injury. J. Heart Lung Transplant. 2019, 38, 1306-1316. [CrossRef]

35. Stone, M.L.; Zhao, Y.; Robert Smith, J.; Weiss, M.L.; Kron, I.L.; Laubach, V.E.; Sharma, A.K. Mesenchymal stromal cell-derived extracellular vesicles attenuate lung ischemia-reperfusion injury and enhance reconditioning of donor lungs after circulatory death. Respir. Res. 2017, 18, 212. [CrossRef] [PubMed]

36. Varkouhi, A.K.; Jerkic, M.; Ormesher, L.; Gagnon, S.; Goyal, S.; Rabani, R.; Masterson, C.; Spring, C.; Chen, P.Z.; Gu, F.X.; et al Extracellular Vesicles from Interferon-gamma-primed Human Umbilical Cord Mesenchymal Stromal Cells Reduce Escherichia coli-induced Acute Lung Injury in Rats. Anesthesiology 2019, 130, 778-790. [CrossRef]

37. Chailakhyan, R.K.; Aver'yanov, A.V.; Zabozlaev, F.G.; Sobolev, P.A.; Sorokina, A.V.; Akul'shin, D.A.; Gerasimov, Y.V. Comparison of the efficiency of transplantation of bone marrow multipotent mesenchymal stromal cells cultured under normoxic and hypoxic conditions and their conditioned media on the model of acute lung injury. Bull. Exp. Biol. Med. 2014, 157, 138-142. [CrossRef]

38. Hayes, M.; Curley, G.F.; Masterson, C.; Devaney, J.; O’Toole, D.; Laffey, J.G. Mesenchymal stromal cells are more effective than the MSC secretome in diminishing injury and enhancing recovery following ventilator-induced lung injury. Intensive Care Med. Exp. 2015, 3, 29. [CrossRef]

39. Hwang, B.; Liles, W.C.; Waworuntu, R.; Mulligan, M.S. Pretreatment with bone marrow-derived mesenchymal stromal cellconditioned media confers pulmonary ischemic tolerance. J. Thorac. Cardiovasc. Surg. 2016, 151, 841-849. [CrossRef]

40. Lu, H.; Poirier, C.; Cook, T.; Traktuev, D.O.; Merfeld-Clauss, S.; Lease, B.; Petrache, I.; March, K.L.; Bogatcheva, N.V. Conditioned media from adipose stromal cells limit lipopolysaccharide-induced lung injury, endothelial hyperpermeability and apoptosis. $J$. Transl. Med. 2015, 13, 67. [CrossRef]

41. Miceli, V.; Bertani, A.; Chinnici, C.M.; Bulati, M.; Pampalone, M.; Amico, G.; Carcione, C.; Schmelzer, E.; Gerlach, J.C.; Conaldi, P.G. Conditioned Medium from Human Amnion-Derived Mesenchymal Stromal/Stem Cells Attenuating the Effects of Cold Ischemia-Reperfusion Injury in an In Vitro Model Using Human Alveolar Epithelial Cells. Int. J. Mol. Sci. 2021, 22, 510. [CrossRef]

42. Moreira, A.; Naqvi, R.; Hall, K.; Emukah, C.; Martinez, J.; Moreira, A.; Dittmar, E.; Zoretic, S.; Evans, M.; Moses, D.; et al. Effects of mesenchymal stromal cell-conditioned media on measures of lung structure and function: A systematic review and meta-analysis of preclinical studies. Stem Cell Res. Ther. 2020, 11, 399. [CrossRef] [PubMed]

43. Shologu, N.; Scully, M.; Laffey, J.G.; O'Toole, D. Human Mesenchymal Stem Cell Secretome from Bone Marrow or AdiposeDerived Tissue Sources for Treatment of Hypoxia-Induced Pulmonary Epithelial Injury. Int. J. Mol. Sci. 2018, 19, 2996. [CrossRef]

44. Khush, K.K.; Cherikh, W.S.; Chambers, D.C.; Goldfarb, S.; Hayes, D., Jr.; Kucheryavaya, A.Y.; Levvey, B.J.; Meiser, B.; Rossano, J.W.; Stehlik, J.; et al. The International Thoracic Organ Transplant Registry of the International Society for Heart and Lung Transplantation: Thirty-fifth Adult Heart Transplantation Report-2018; Focus Theme: Multiorgan Transplantation. J. Heart Lung Transplant. 2018, 37, 1155-1168. [CrossRef] [PubMed]

45. Lyu, D.M.; Goff, R.R.; Chan, K.M. The Lung Allocation Score and Its Relevance. Semin. Respir. Crit. Care Med. 2021, 42, 346-356. [CrossRef] [PubMed]

46. Valapour, M.; Skeans, M.A.; Heubner, B.M.; Smith, J.M.; Hertz, M.I.; Edwards, L.B.; Cherikh, W.S.; Callahan, E.R.; Snyder, J.J.; Israni, A.K.; et al. OPTN/SRTR 2013 Annual Data Report: Lung. Am. J. Transplant. 2015, 15 (Suppl. 2), 1-28. [CrossRef]

47. Weill, D. Access to Lung Transplantation. The Long and Short of It. Am. J. Respir. Crit. Care Med. 2016, 193, 605-606. [CrossRef]

48. Krutsinger, D.; Reed, R.M.; Blevins, A.; Puri, V.; De Oliveira, N.C.; Zych, B.; Bolukbas, S.; Van Raemdonck, D.; Snell, G.I.; Eberlein, M. Lung transplantation from donation after cardiocirculatory death: A systematic review and meta-analysis. J. Heart Lung Transplant. 2015, 34, 675-684. [CrossRef]

49. Reeb, J.; Keshavjee, S.; Cypel, M. Expanding the lung donor pool: Advancements and emerging pathways. Curr. Opin. Organ. Transplant. 2015, 20, 498-505. [CrossRef]

50. Halpern, S.D.; Hasz, R.D.; Abt, P.L. Incidence and distribution of transplantable organs from donors after circulatory determination of death in U.S. intensive care units. Ann. Am. Thorac. Soc. 2013, 10, 73-80. [CrossRef]

51. Levvey, B.J.; Harkess, M.; Hopkins, P.; Chambers, D.; Merry, C.; Glanville, A.R.; Snell, G.I. Excellent clinical outcomes from a national donation-after-determination-of-cardiac-death lung transplant collaborative. Am. J. Transplant. 2012, 12, $2406-2413$. [CrossRef] [PubMed]

52. Meers, C.; Van Raemdonck, D.; Verleden, G.M.; Coosemans, W.; Decaluwe, H.; De Leyn, P.; Nafteux, P.; Lerut, T. The number of lung transplants can be safely doubled using extended criteria donors; a single-center review. Transpl. Int. 2010, 23, 628-635. [CrossRef]

53. Wigfield, C. Donation after cardiac death for lung transplantation: A review of current clinical practice. Curr. Opin. Organ. Transplant. 2014, 19, 455-459. [CrossRef] [PubMed] 
54. Gomez-de-Antonio, D.; Campo-Canaveral, J.L.; Crowley, S.; Valdivia, D.; Cordoba, M.; Moradiellos, J.; Naranjo, J.M.; Ussetti, P.; Varela, A. Clinical lung transplantation from uncontrolled non-heart-beating donors revisited. J. Heart Lung Transplant. 2012, 31, 349-353. [CrossRef] [PubMed]

55. Munshi, L.; Keshavjee, S.; Cypel, M. Donor management and lung preservation for lung transplantation. Lancet Respir. Med. 2013, 1, 318-328. [CrossRef]

56. Steen, S.; Ingemansson, R.; Eriksson, L.; Pierre, L.; Algotsson, L.; Wierup, P.; Liao, Q.; Eyjolfsson, A.; Gustafsson, R.; Sjoberg, T. First human transplantation of a nonacceptable donor lung after reconditioning ex vivo. Ann. Thorac. Surg. 2007, 83, 2191-2194. [CrossRef] [PubMed]

57. Steen, S.; Sjoberg, T.; Pierre, L.; Liao, Q.; Eriksson, L.; Algotsson, L. Transplantation of lungs from a non-heart-beating donor. Lancet 2001, 357, 825-829. [CrossRef]

58. Cypel, M.; Yeung, J.C.; Liu, M.; Anraku, M.; Chen, F.; Karolak, W.; Sato, M.; Laratta, J.; Azad, S.; Madonik, M.; et al. Normothermic ex vivo lung perfusion in clinical lung transplantation. Gen. Thorac. Cardiovasc Surg. 2011, 364, 1431-1440. [CrossRef]

59. Cypel, M.; Yeung, J.C.; Hirayama, S.; Rubacha, M.; Fischer, S.; Anraku, M.; Sato, M.; Harwood, S.; Pierre, A.; Waddell, T.K.; et al. Technique for prolonged normothermic ex vivo lung perfusion. J. Heart Lung Transplant. 2008, 27, 1319-1325. [CrossRef]

60. Machuca, T.N.; Cypel, M. Ex vivo lung perfusion. J. Thorac Dis. 2014, 6, 1054-1062.

61. Tikkanen, J.M.; Cypel, M.; Machuca, T.N.; Azad, S.; Binnie, M.; Chow, C.W.; Chaparro, C.; Hutcheon, M.; Yasufuku, K.; de Perrot, M.; et al. Functional outcomes and quality of life after normothermic ex vivo lung perfusion lung transplantation. J. Heart Lung Transplant. 2015, 34, 547-556. [CrossRef]

62. Iske, J.; Hinze, C.A.; Salman, J.; Haverich, A.; Tullius, S.G.; Ius, F. The potential of ex vivo lung perfusion on improving organ quality and ameliorating ischemia reperfusion injury. Am. J. Transplant. 2021, 21, 3831-3839. [CrossRef] [PubMed]

63. Wagner, C.E.; Pope, N.H.; Charles, E.J.; Huerter, M.E.; Sharma, A.K.; Salmon, M.D.; Carter, B.T.; Stoler, M.H.; Lau, C.L.; Laubach, V.E.; et al. Ex vivo lung perfusion with adenosine A2A receptor agonist allows prolonged cold preservation of lungs donated after cardiac death. J. Thorac. Cardiovasc. Surg. 2016, 151, 538-545. [CrossRef]

64. Cypel, M.; Liu, M.; Rubacha, M.; Yeung, J.C.; Hirayama, S.; Anraku, M.; Sato, M.; Medin, J.; Davidson, B.L.; de Perrot, M.; et al Functional repair of human donor lungs by IL-10 gene therapy. Sci. Transl. Med. 2009, 1, 4ra9. [CrossRef] [PubMed]

65. Nakajima, D.; Watanabe, Y.; Ohsumi, A.; Pipkin, M.; Chen, M.; Mordant, P.; Kanou, T.; Saito, T.; Lam, R.; Coutinho, R.; et al. Mesenchymal stromal cell therapy during ex vivo lung perfusion ameliorates ischemia-reperfusion injury in lung transplantation. J. Heart Lung Transplant. 2019, 38, 1214-1223. [CrossRef]

66. Zuk, P.A.; Zhu, M.; Ashjian, P.; De Ugarte, D.A.; Huang, J.I.; Mizuno, H.; Alfonso, Z.C.; Fraser, J.K.; Benhaim, P.; Hedrick, M.H. Human adipose tissue is a source of multipotent stem cells. Mol. Biol. Cell. 2002, 13, 4279-4295. [CrossRef] [PubMed]

67. Colter, D.C.; Class, R.; DiGirolamo, C.M.; Prockop, D.J. Rapid expansion of recycling stem cells in cultures of plastic-adherent cells from human bone marrow. Proc. Natl. Acad. Sci. USA 2000, 97, 3213-3218. [CrossRef] [PubMed]

68. Gronthos, S.; Mankani, M.; Brahim, J.; Robey, P.G.; Shi, S. Postnatal human dental pulp stem cells (DPSCs) in vitro and in vivo. Proc. Natl. Acad. Sci. USA 2000, 97, 13625-13630. [CrossRef]

69. Miranda, J.P.; Filipe, E.; Fernandes, A.S.; Almeida, J.M.; Martins, J.P.; De la Fuente, A.; Abal, M.; Barcia, R.N.; Cruz, P.; Cruz, H.; et al. The Human Umbilical Cord Tissue-Derived MSC Population UCX((R)) Promotes Early Motogenic Effects on Keratinocytes and Fibroblasts and G-CSF-Mediated Mobilization of BM-MSCs When Transplanted In Vivo. Cell Transplant. 2015, 24, 865-877. [CrossRef]

70. Parolini, O.; Alviano, F.; Bagnara, G.P.; Bilic, G.; Buhring, H.J.; Evangelista, M.; Hennerbichler, S.; Liu, B.; Magatti, M.; Mao, N.; et al. Concise review: Isolation and characterization of cells from human term placenta: Outcome of the first international Workshop on Placenta Derived Stem Cells. Stem Cells 2008, 26, 300-311. [CrossRef]

71. Keating, A. Mesenchymal stromal cells: New directions. Cell Stem Cell 2012, 10, 709-716. [CrossRef] [PubMed]

72. Hass, R.; Kasper, C.; Bohm, S.; Jacobs, R. Different populations and sources of human mesenchymal stem cells (MSC): A comparison of adult and neonatal tissue-derived MSC. Cell Commun. Signal. CCS 2011, 9, 12. [CrossRef]

73. Miceli, V.; Pampalone, M.; Vella, S.; Carreca, A.P.; Amico, G.; Conaldi, P.G. Comparison of Immunosuppressive and Angiogenic Properties of Human Amnion-Derived Mesenchymal Stem Cells between 2D and 3D Culture Systems. Stem Cells Int. 2019, 2019, 7486279. [CrossRef] [PubMed]

74. Naji, A.; Eitoku, M.; Favier, B.; Deschaseaux, F.; Rouas-Freiss, N.; Suganuma, N. Biological functions of mesenchymal stem cells and clinical implications. Cell Mol. Life Sci. 2019, 76, 3323-3348. [CrossRef]

75. Parolini, O.; Soncini, M.; Evangelista, M.; Schmidt, D. Amniotic membrane and amniotic fluid-derived cells: Potential tools for regenerative medicine? Regen. Med. 2009, 4, 275-291. [CrossRef] [PubMed]

76. Pittenger, M.F.; Mackay, A.M.; Beck, S.C.; Jaiswal, R.K.; Douglas, R.; Mosca, J.D.; Moorman, M.A.; Simonetti, D.W.; Craig, S.; Marshak, D.R. Multilineage potential of adult human mesenchymal stem cells. Science 1999, 284, 143-147. [CrossRef]

77. Bani-Yaghoub, M.; Wilson, P.; Hengstschlager, M.; Nikaido, T.; Pei, D. Amniotic stem cells: Potential in regenerative medicine. Stem Cells Int. 2012, 2012, 530674. [CrossRef] [PubMed]

78. Kern, S.; Eichler, H.; Stoeve, J.; Kluter, H.; Bieback, K. Comparative analysis of mesenchymal stem cells from bone marrow, umbilical cord blood, or adipose tissue. Stem Cells 2006, 24, 1294-1301. [CrossRef]

79. Degirmenci, B.; Valenta, T.; Dimitrieva, S.; Hausmann, G.; Basler, K. GLI1-expressing mesenchymal cells form the essential Wnt-secreting niche for colon stem cells. Nature 2018, 558, 449-453. [CrossRef] 
80. Kolf, C.M.; Cho, E.; Tuan, R.S. Mesenchymal stromal cells. Biology of adult mesenchymal stem cells: Regulation of niche, self-renewal and differentiation. Arthritis Res. Ther. 2007, 9, 204. [CrossRef]

81. Wosczyna, M.N.; Konishi, C.T.; Perez Carbajal, E.E.; Wang, T.T.; Walsh, R.A.; Gan, Q.; Wagner, M.W.; Rando, T.A. Mesenchymal Stromal Cells Are Required for Regeneration and Homeostatic Maintenance of Skeletal Muscle. Cell Rep. 2019, 27, $2029-2035$ e5. [CrossRef]

82. Morrison, S.J.; Scadden, D.T. The bone marrow niche for haematopoietic stem cells. Nature 2014, 505, 327-334. [CrossRef]

83. Aggarwal, S.; Pittenger, M.F. Human mesenchymal stem cells modulate allogeneic immune cell responses. Blood 2005, 105, (4), 1815-1822. [CrossRef]

84. Bulati, M.; Miceli, V.; Gallo, A.; Amico, G.; Carcione, C.; Pampalone, M.; Conaldi, P.G. The Immunomodulatory Properties of the Human Amnion-Derived Mesenchymal Stromal/Stem Cells Are Induced by INF-gamma Produced by Activated Lymphomonocytes and Are Mediated by Cell-To-Cell Contact and Soluble Factors. Front. Immunol. 2020, 11, 54. [CrossRef] [PubMed]

85. Chamberlain, G.; Fox, J.; Ashton, B.; Middleton, J. Concise review: Mesenchymal stem cells: Their phenotype, differentiation capacity, immunological features, and potential for homing. Stem Cells 2007, 25, 2739-2749. [CrossRef]

86. Cheng, Z.; Ou, L.; Zhou, X.; Li, F.; Jia, X.; Zhang, Y.; Liu, X.; Li, Y.; Ward, C.A.; Melo, L.G.; et al. Targeted migration of mesenchymal stem cells modified with CXCR4 gene to infarcted myocardium improves cardiac performance. Mol. Ther. J. Am. Soc. Gene Ther. 2008, 16, 571-579. [CrossRef]

87. Henschler, R.; Deak, E.; Seifried, E. Homing of Mesenchymal Stem Cells. Transfus. Med. Hemotherapy: Off. Organ. Der Dtsch. Ges. Fur Transfus. Und Immunhamatol. 2008, 35, 306-312. [CrossRef]

88. Galipeau, J.; Sensebe, L. Mesenchymal Stromal Cells: Clinical Challenges and Therapeutic Opportunities. Cell Stem Cell 2018, 22, 824-833. [CrossRef] [PubMed]

89. Phinney, D.G.; Galipeau, J.; Krampera, M.; Martin, I.; Shi, Y.; Sensebe, L. MSCs: Science and trials. Nat. Med. 2013, 19, 812. [CrossRef] [PubMed]

90. Squillaro, T.; Peluso, G.; Galderisi, U. Clinical Trials With Mesenchymal Stem Cells: An Update. Cell Transplant. 2016, 25, 829-848. [CrossRef] [PubMed]

91. Trounson, A.; McDonald, C. Stem Cell Therapies in Clinical Trials: Progress and Challenges. Cell Stem Cell 2015, 17, 11-22. [CrossRef]

92. Wei, X.; Yang, X.; Han, Z.P.; Qu, F.F.; Shao, L.; Shi, Y.F. Mesenchymal stem cells: A new trend for cell therapy. Acta Pharmacol. Sin. 2013, 34, 747-754. [CrossRef] [PubMed]

93. Jacobs, S.A.; Roobrouck, V.D.; Verfaillie, C.M.; Van Gool, S.W. Immunological characteristics of human mesenchymal stem cells and multipotent adult progenitor cells. Immunol. Cell Biol. 2013, 91, 32-39. [CrossRef] [PubMed]

94. Le Blanc, K.; Tammik, C.; Rosendahl, K.; Zetterberg, E.; Ringden, O. HLA expression and immunologic properties of differentiated and undifferentiated mesenchymal stem cells. Exp. Hematol. 2003, 31, 890-896. [CrossRef]

95. Ullah, I.; Subbarao, R.B.; Rho, G.J. Human mesenchymal stem cells - current trends and future prospective. Biosci. Rep. 2015, 35, e00191. [CrossRef]

96. Poggi, A.; Zocchi, M.R. Immunomodulatory Properties of Mesenchymal Stromal Cells: Still Unresolved "Yin and Yang". Curr. Stem Cell Res. Ther. 2019, 14, 344-350. [CrossRef]

97. Fu, Y.; Karbaat, L.; Wu, L.; Leijten, J.; Both, S.K.; Karperien, M. Trophic Effects of Mesenchymal Stem Cells in Tissue Regeneration. Tissue Eng.. Part. B Rev. 2017, 23, 515-528. [CrossRef]

98. Tao, H.; Han, Z.; Han, Z.C.; Li, Z. Proangiogenic Features of Mesenchymal Stem Cells and Their Therapeutic Applications. Stem Cells Int. 2016, 2016, 1314709. [CrossRef]

99. Stavely, R.; Nurgali, K. The emerging antioxidant paradigm of mesenchymal stem cell therapy. Stem Cells Transl. Med. 2020, 9, 985-1006. [CrossRef]

100. Harrell, C.R.; Fellabaum, C.; Jovicic, N.; Djonov, V.; Arsenijevic, N.; Volarevic, V. Molecular Mechanisms Responsible for Therapeutic Potential of Mesenchymal Stem Cell-Derived Secretome. Cells 2019, 8, 467. [CrossRef] [PubMed]

101. Wu, X.; Jiang, J.; Gu, Z.; Zhang, J.; Chen, Y.; Liu, X. Mesenchymal stromal cell therapies: Immunomodulatory properties and clinical progress. Stem Cell Res. Ther. 2020, 11, 345. [CrossRef] [PubMed]

102. Horton, J.A.; Hudak, K.E.; Chung, E.J.; White, A.O.; Scroggins, B.T.; Burkeen, J.F.; Citrin, D.E. Mesenchymal stem cells inhibit cutaneous radiation-induced fibrosis by suppressing chronic inflammation. Stem Cells 2013, 31, 2231-2241. [CrossRef]

103. Jankowski, M.; Dompe, C.; Sibiak, R.; Wasiatycz, G.; Mozdziak, P.; Jaskowski, J.M.; Antosik, P.; Kempisty, B.; DyszkiewiczKonwinska, M. In Vitro Cultures of Adipose-Derived Stem Cells: An Overview of Methods, Molecular Analyses, and Clinical Applications. Cells 2020, 9, 1783. [CrossRef] [PubMed]

104. Leuning, D.G.; Beijer, N.R.M.; du Fosse, N.A.; Vermeulen, S.; Lievers, E.; van Kooten, C.; Rabelink, T.J.; Boer, J. The cytokine secretion profile of mesenchymal stromal cells is determined by surface structure of the microenvironment. Sci. Rep. 2018, 8, 7716. [CrossRef] [PubMed]

105. Miceli, V.; Chinnici, C.M.; Bulati, M.; Pampalone, M.; Amico, G.; Schmelzer, E.; Gerlach, J.C.; Conaldi, P.G. Comparative study of the production of soluble factors in human placenta-derived mesenchymal stromal/stem cells grown in adherent conditions or as aggregates in a catheter-like device. Biochem. Biophys. Res. Commun. 2020, 522, 171-176. [CrossRef] 
106. Nikolits, I.; Nebel, S.; Egger, D.; Kress, S.; Kasper, C. Towards Physiologic Culture Approaches to Improve Standard Cultivation of Mesenchymal Stem Cells. Cells 2021, 10, 886. [CrossRef]

107. Newman, R.E.; Yoo, D.; LeRoux, M.A.; Danilkovitch-Miagkova, A. Treatment of inflammatory diseases with mesenchymal stem cells. Inflamm. Allergy Drug Targets 2009, 8, 110-123. [CrossRef]

108. Foronjy, R.F.; Majka, S.M. The potential for resident lung mesenchymal stem cells to promote functional tissue regeneration: Understanding microenvironmental cues. Cells 2012, 1, 874. [CrossRef]

109. Gnecchi, M.; Zhang, Z.; Ni, A.; Dzau, V.J. Paracrine mechanisms in adult stem cell signaling and therapy. Circ. Res. 2008, 103, 1204-1219. [CrossRef]

110. Eefting, F.; Rensing, B.; Wigman, J.; Pannekoek, W.J.; Liu, W.M.; Cramer, M.J.; Lips, D.J.; Doevendans, P.A. Role of apoptosis in reperfusion injury. Cardiovasc. Res. 2004, 61, 414-426. [CrossRef]

111. Li, J.H.; Zhang, N.; Wang, J.A. Improved anti-apoptotic and anti-remodeling potency of bone marrow mesenchymal stem cells by anoxic pre-conditioning in diabetic cardiomyopathy. J. Endocrinol. Investig. 2008, 31, 103-110. [CrossRef]

112. Lee, S.C.; Kim, J.O.; Kim, S.J. Secretome from human adipose-derived stem cells protects mouse liver from hepatic ischemiareperfusion injury. Surgery 2015, 157, 934-943. [CrossRef]

113. Gyorgy, B.; Szabo, T.G.; Pasztoi, M.; Pal, Z.; Misjak, P.; Aradi, B.; Laszlo, V.; Pallinger, E.; Pap, E.; Kittel, A.; et al. Membrane vesicles, current state-of-the-art: Emerging role of extracellular vesicles. Cell Mol. Life Sci. 2011, 68, 2667-2688. [CrossRef] [PubMed]

114. Harrell, C.R.; Jovicic, N.; Djonov, V.; Arsenijevic, N.; Volarevic, V. Mesenchymal Stem Cell-Derived Exosomes and Other Extracellular Vesicles as New Remedies in the Therapy of Inflammatory Diseases. Cells 2019, 8, 1605. [CrossRef] [PubMed]

115. Tomasoni, S.; Longaretti, L.; Rota, C.; Morigi, M.; Conti, S.; Gotti, E.; Capelli, C.; Introna, M.; Remuzzi, G.; Benigni, A. Transfer of growth factor receptor mRNA via exosomes unravels the regenerative effect of mesenchymal stem cells. Stem Cells Dev. 2013, 22, 772-780. [CrossRef]

116. van den Akker, F.; Vrijsen, K.R.; Deddens, J.C.; Buikema, J.W.; Mokry, M.; van Laake, L.W.; Doevendans, P.A.; Sluijter, J.P.G Suppression of T cells by mesenchymal and cardiac progenitor cells is partly mediated via extracellular vesicles. Heliyon 2018, 4 e00642. [CrossRef] [PubMed]

117. Gatti, S.; Bruno, S.; Deregibus, M.C.; Sordi, A.; Cantaluppi, V.; Tetta, C.; Camussi, G. Microvesicles derived from human adult mesenchymal stem cells protect against ischaemia-reperfusion-induced acute and chronic kidney injury. Nephrol. Dial. Transplant. Off. Publ. Eur. Dial. Transpl. Assoc. - Eur. Ren. Assoc. 2011, 26, 1474-1483. [CrossRef]

118. Wilkey, B.J.; Abrams, B.A. Mitigation of Primary Graft Dysfunction in Lung Transplantation: Current Understanding and Hopes for the Future. Semin. Cardiothorac. Vasc. Anesth. 2020, 24, 54-66. [CrossRef]

119. Christie, J.D.; Kotloff, R.M.; Ahya, V.N.; Tino, G.; Pochettino, A.; Gaughan, C.; DeMissie, E.; Kimmel, S.E. The effect of primary graft dysfunction on survival after lung transplantation. Am. J. Respir. Crit. Care Med. 2005, 171, 1312-1316. [CrossRef]

120. Jarvinen, L.; Badri, L.; Wettlaufer, S.; Ohtsuka, T.; Standiford, T.J.; Toews, G.B.; Pinsky, D.J.; Peters-Golden, M.; Lama, V.N. Lung resident mesenchymal stem cells isolated from human lung allografts inhibit T cell proliferation via a soluble mediator. J. Immunol. 2008, 181, 4389-4396. [CrossRef]

121. Chambers, D.C.; Enever, D.; Lawrence, S.; Sturm, M.J.; Herrmann, R.; Yerkovich, S.; Musk, M.; Hopkins, P.M. Mesenchymal Stromal Cell Therapy for Chronic Lung Allograft Dysfunction: Results of a First-in-Man Study. Stem Cells Transl. Med. 2017, 6, 1152-1157. [CrossRef]

122. Guillamat-Prats, R.; Camprubi-Rimblas, M.; Puig, F.; Herrero, R.; Tantinya, N.; Serrano-Mollar, A.; Artigas, A. Alveolar Type II Cells or Mesenchymal Stem Cells: Comparison of Two Different Cell Therapies for the Treatment of Acute Lung Injury in Rats. Cells 2020, 9, 1816. [CrossRef]

123. Ahn, S.Y.; Park, W.S.; Kim, Y.E.; Sung, D.K.; Sung, S.I.; Ahn, J.Y.; Chang, Y.S. Vascular endothelial growth factor mediates the therapeutic efficacy of mesenchymal stem cell-derived extracellular vesicles against neonatal hyperoxic lung injury. Exp. Mol. Med. 2018, 50, 1-12. [CrossRef] [PubMed]

124. Aliotta, J.M.; Pereira, M.; Wen, S.; Dooner, M.S.; Del Tatto, M.; Papa, E.; Goldberg, L.R.; Baird, G.L.; Ventetuolo, C.E.; Quesenberry, P.J.; et al. Exosomes induce and reverse monocrotaline-induced pulmonary hypertension in mice. Cardiovasc. Res. 2016, 110, 319-330. [CrossRef] [PubMed]

125. Chen, S.; Chen, L.; Wu, X.; Lin, J.; Fang, J.; Chen, X.; Wei, S.; Xu, J.; Gao, Q.; Kang, M. Ischemia postconditioning and mesenchymal stem cells engraftment synergistically attenuate ischemia reperfusion-induced lung injury in rats. J. Surg. Res. 2012, 178, 81-91. [CrossRef] [PubMed]

126. Devaney, J.; Horie, S.; Masterson, C.; Elliman, S.; Barry, F.; O’Brien, T.; Curley, G.F.; O’Toole, D.; Laffey, J.G. Human mesenchymal stromal cells decrease the severity of acute lung injury induced by E. coli in the rat. Thorax 2015, 70, 625-635. [CrossRef] [PubMed]

127. Gulasi, S.; Atici, A.; Yilmaz, S.N.; Polat, A.; Yilmaz, M.; Lacin, M.T.; Orekici, G.; Celik, Y. Mesenchymal stem cell treatment in hyperoxia-induced lung injury in newborn rats. Pediatrics Int. Off. J. Jpn. Pediatric Soc. 2016, 58, 206-213. [CrossRef]

128. Huh, J.W.; Kim, S.Y.; Lee, J.H.; Lee, J.S.; Van Ta, Q.; Kim, M.; Oh, Y.M.; Lee, Y.S.; Lee, S.D. Bone marrow cells repair cigarette smoke-induced emphysema in rats. Am. J. Physiol. Lung Cell Mol. Physiol. 2011, 301, L255-L266. [CrossRef]

129. Ionescu, L.; Byrne, R.N.; van Haaften, T.; Vadivel, A.; Alphonse, R.S.; Rey-Parra, G.J.; Weissmann, G.; Hall, A.; Eaton, F.; Thebaud, B. Stem cell conditioned medium improves acute lung injury in mice: In vivo evidence for stem cell paracrine action. Am. $J$. Physiol. Lung Cell Mol. Physiol. 2012, 303, L967-L977. [CrossRef] 
130. Kennelly, H.; Mahon, B.P.; English, K. Human mesenchymal stromal cells exert HGF dependent cytoprotective effects in a human relevant pre-clinical model of COPD. Sci. Rep. 2016, 6, 38207. [CrossRef]

131. Kim, Y.S.; Kim, J.Y.; Cho, R.; Shin, D.M.; Lee, S.W.; Oh, Y.M. Adipose stem cell-derived nanovesicles inhibit emphysema primarily via an FGF2-dependent pathway. Exp. Mol. Med. 2017, 49, e284. [CrossRef] [PubMed]

132. Ni, S.; Wang, D.; Qiu, X.; Pang, L.; Song, Z.; Guo, K. Bone marrow mesenchymal stem cells protect against bleomycin-induced pulmonary fibrosis in rat by activating Nrf2 signaling. Int. J. Clin. Exp. Pathol. 2015, 8, 7752-7761. [PubMed]

133. Pacienza, N.; Santa-Cruz, D.; Malvicini, R.; Robledo, O.; Lemus-Larralde, G.; Bertolotti, A.; Marcos, M.; Yannarelli, G. Mesenchymal Stem Cell Therapy Facilitates Donor Lung Preservation by Reducing Oxidative Damage during Ischemia. Stem Cells Int. 2019, 2019, 8089215. [CrossRef]

134. Sadeghi, S.; Mosaffa, N.; Hashemi, S.M.; Mehdi Naghizadeh, M.; Ghazanfari, T. The immunomodulatory effects of mesenchymal stem cells on long term pulmonary complications in an animal model exposed to a sulfur mustard analog. Int. Immunopharmacol. 2020, 80, 105879. [CrossRef] [PubMed]

135. Shen, Q.; Chen, B.; Xiao, Z.; Zhao, L.; Xu, X.; Wan, X.; Jin, M.; Dai, J.; Dai, H. Paracrine factors from mesenchymal stem cells attenuate epithelial injury and lung fibrosis. Mol. Med. Rep. 2015, 11, 2831-2837. [CrossRef]

136. Wakayama, H.; Hashimoto, N.; Matsushita, Y.; Matsubara, K.; Yamamoto, N.; Hasegawa, Y.; Ueda, M.; Yamamoto, A. Factors secreted from dental pulp stem cells show multifaceted benefits for treating acute lung injury in mice. Cytotherapy 2015, 17, 1119-1129. [CrossRef] [PubMed]

137. Wittwer, T.; Rahmanian, P.; Choi, Y.H.; Zeriouh, M.; Karavidic, S.; Neef, K.; Christmann, A.; Piatkowski, T.; Schnapper, A.; Ochs, M.; et al. Mesenchymal stem cell pretreatment of non-heart-beating-donors in experimental lung transplantation. J. Cardiothorac. Surg. 2014, 9, 151. [CrossRef]

138. Zhu, Y.G.; Feng, X.M.; Abbott, J.; Fang, X.H.; Hao, Q.; Monsel, A.; Qu, J.M.; Matthay, M.A.; Lee, J.W. Human mesenchymal stem cell microvesicles for treatment of Escherichia coli endotoxin-induced acute lung injury in mice. Stem Cells 2014, 32, 116-125. [CrossRef]

139. Sun, C.K.; Yen, C.H.; Lin, Y.C.; Tsai, T.H.; Chang, L.T.; Kao, Y.H.; Chua, S.; Fu, M.; Ko, S.F.; Leu, S.; et al. Autologous transplantation of adipose-derived mesenchymal stem cells markedly reduced acute ischemia-reperfusion lung injury in a rodent model. J. Transl. Med. 2011, 9, 118. [CrossRef]

140. Mordant, P.; Nakajima, D.; Kalaf, R.; Iskender, I.; Maahs, L.; Behrens, P.; Coutinho, R.; Iyer, R.K.; Davies, J.E.; Cypel, M.; et al Mesenchymal stem cell treatment is associated with decreased perfusate concentration of interleukin-8 during ex vivo perfusion of donor lungs after 18-hour preservation. J. Heart Lung Transplant. 2016, 35, 1245-1254. [CrossRef]

141. Gennai, S.; Monsel, A.; Hao, Q.; Park, J.; Matthay, M.A.; Lee, J.W. Microvesicles Derived From Human Mesenchymal Stem Cells Restore Alveolar Fluid Clearance in Human Lungs Rejected for Transplantation. Am. J. Transplant. 2015, 15, 2404-2412. [CrossRef] [PubMed]

142. Wu, M.Y.; Yiang, G.T.; Liao, W.T.; Tsai, A.P.; Cheng, Y.L.; Cheng, P.W.; Li, C.Y.; Li, C.J. Current Mechanistic Concepts in Ischemia and Reperfusion Injury. Cell. Physiol. Biochem. 2018, 46, 1650-1667. [CrossRef] [PubMed]

143. Slegtenhorst, B.R.; Dor, F.J.; Rodriguez, H.; Voskuil, F.J.; Tullius, S.G. Ischemia/reperfusion Injury and its Consequences on Immunity and Inflammation. Curr. Transplant. Rep. 2014, 1, 147-154. [CrossRef] [PubMed]

144. Ponticelli, C.E. The impact of cold ischemia time on renal transplant outcome. Kidney Int. 2015, 87, 272-275. [CrossRef]

145. Oliva, J. Therapeutic Properties of Mesenchymal Stem Cell on Organ Ischemia-Reperfusion Injury. Int. J. Mol. Sci. 2019, 20, 5511. [CrossRef]

146. Takamura, M.; Usui, S.; Inoue, O.; Ootsuji, H.; Takashima, S.I.; Nomura, A.; Kato, T.; Murai, H.; Furusho, H.; Sakai, Y.; et al. Adipose-derived regenerative cells exert beneficial effects on systemic responses following myocardial ischemia/reperfusion. Cardiol. J. 2016, 23, 685-693. [CrossRef] [PubMed]

147. Cui, X.; He, Z.; Liang, Z.; Chen, Z.; Wang, H.; Zhang, J. Exosomes From Adipose-derived Mesenchymal Stem Cells Protect the Myocardium Against Ischemia/Reperfusion Injury Through Wnt/beta-Catenin Signaling Pathway. J. Cardiovasc. Pharmacol. 2017, 70, 225-231. [CrossRef]

148. Mias, C.; Trouche, E.; Seguelas, M.H.; Calcagno, F.; Dignat-George, F.; Sabatier, F.; Piercecchi-Marti, M.D.; Daniel, L.; Bianchi, P.; Calise, D.; et al. Ex vivo pretreatment with melatonin improves survival, proangiogenic/mitogenic activity, and efficiency of mesenchymal stem cells injected into ischemic kidney. Stem Cells 2008, 26, 1749-1757. [CrossRef]

149. Haga, H.; Yan, I.K.; Borrelli, D.A.; Matsuda, A.; Parasramka, M.; Shukla, N.; Lee, D.D.; Patel, T. Extracellular vesicles from bone marrow-derived mesenchymal stem cells protect against murine hepatic ischemia/reperfusion injury. Liver Transpl. 2017, 23, 791-803. [CrossRef]

150. Li, S.; Zheng, X.; Li, H.; Zheng, J.; Chen, X.; Liu, W.; Tai, Y.; Zhang, Y.; Wang, G.; Yang, Y. Mesenchymal Stem Cells Ameliorate Hepatic Ischemia/Reperfusion Injury via Inhibition of Neutrophil Recruitment. J. Immunol. Res. 2018, 2018, 7283703. [CrossRef]

151. Zare, M.A.; Zare, A.; Azarpira, N.; Pakbaz, S. The protective effect of bone marrow-derived mesenchymal stem cells in liver ischemia/reperfusion injury via down-regulation of miR-370. Iran. J. Basic Med. Sci. 2019, 22, 683-689.

152. Lu, W.; Si, Y.I.; Ding, J.; Chen, X.; Zhang, X.; Dong, Z.; Fu, W. Mesenchymal stem cells attenuate acute ischemia-reperfusion injury in a rat model. Exp. Ther. Med. 2015, 10, 2131-2137. [CrossRef] [PubMed]

153. Neizer, H.; Singh, G.B.; Gupta, S.; Singh, S.K. Addressing donor-organ shortages using extended criteria in lung transplantation. Ann. Cardiothorac. Surg. 2020, 9, 49-50. [CrossRef] 
154. Rosso, L.; Zanella, A.; Righi, I.; Barilani, M.; Lazzari, L.; Scotti, E.; Gori, F.; Mendogni, P. Lung transplantation, ex-vivo reconditioning and regeneration: State of the art and perspectives. J. Thorac Dis. 2018, 10, S2423-S2430. [CrossRef] [PubMed]

155. Lonati, C.; Bassani, G.A.; Brambilla, D.; Leonardi, P.; Carlin, A.; Faversani, A.; Gatti, S.; Valenza, F. Influence of ex vivo perfusion on the biomolecular profile of rat lungs. FASEB J. 2018, 32, 5532-5549. [CrossRef]

156. Roffia, V.; De Palma, A.; Lonati, C.; Di Silvestre, D.; Rossi, R.; Mantero, M.; Gatti, S.; Dondossola, D.; Valenza, F.; Mauri, P.; et al. Proteome Investigation of Rat Lungs subjected to Ex Vivo Perfusion (EVLP). Molecules 2018, 23, 3061. [CrossRef] [PubMed]

157. Shin, J.; Hsin, M.K.; Baciu, C.; Chen, Y.; Zamel, R.; Machuca, T.; Yeung, J.; Cypel, M.; Keshavjee, S.; Liu, M. Use of metabolomics to identify strategies to improve and prolong ex vivo lung perfusion for lung transplants. J. Heart Lung Transplant. 2021, 40, 525-535. [CrossRef]

158. Wilson, J.G.; Liu, K.D.; Zhuo, H.; Caballero, L.; McMillan, M.; Fang, X.; Cosgrove, K.; Vojnik, R.; Calfee, C.S.; Lee, J.W.; et al. Mesenchymal stem (stromal) cells for treatment of ARDS: A phase 1 clinical trial. Lancet Respir. Med. 2015, 3, 24-32. [CrossRef]

159. Walter, J.; Ware, L.B.; Matthay, M.A. Mesenchymal stem cells: Mechanisms of potential therapeutic benefit in ARDS and sepsis. Lancet Respir. Med. 2014, 2, 1016-1026. [CrossRef] 